\title{
Economic assessment of the production potential of medicinal plants in Ukraine
}

\author{
Tetiana Mirzoieva ${ }^{1,}{ }^{*}$, Alona Chupriak $^{1}$, BogdanAvramchuk ${ }^{1}$, Violeta Heraimovych $^{1}$, and \\ Liliya Ilkiv $^{1}$ \\ ${ }^{1}$ National University of Life and Enviromental Sciences of Ukraine, Ukraine
}

\begin{abstract}
The article is devoted to the study of the production potential of medicinal plant growing in Ukraine. The role and significance of the production of medicinal plants in a pandemic and climate crisis are revealed, attention is focused on the economic feasibility of their production. The profitability, profitability, profitability and cost of their production are analyzed on the example of the most widespread in Ukraine cultivated medicinal plants and the expediency of its development is substantiated.It was found that the main deterrent to the development of medicinal plants is the high production costs in the first year after the start of production. The general and economic advantages, and also features of production of medicinal plants, in comparison with other crops, in particular grain, are defined;a comparison of average sales prices of cereals and legumes, vegetables, fruits and berries and medicinal crops. The economic feasibility of their processing is demonstrated on the example of value chains in the context of individual medicinal plants. Attention is paid to the most common ways of selling medicinal plants, their advantages and disadvantages are identified. Based on the performed economic assessment of the production potential of medicinal crop production in Ukraine, a set of financial and economic instruments has been identified, the introduction of which is necessary for the development of the industry.
\end{abstract}

\section{Introduction}

In the modern world economy, some industries are disappearing and completely new ones are appearing or those whose demand for products is growing at this stage of human society are becoming more important. In such conditions of transformation of the world economy in general and national economies in particular, and in the conditions of climate crisis the importance of a specific and highly profitable segment of agricultural production - medicinal plant -is increasing, the development of which is inextricably linked with human history. First of all, medicinal plants were and now are the raw material for the production of drugs, which cure many diseases and this determines their importance for humanity. In recent decades, more and more alternative medicine and herbal medicines are being chosen by buyers as preventive measures to maintain immunity and overall body tone. 2020 was a turning point for world production of medicinal plants. For example, in

\footnotetext{
*Corresponding author: mirzoeva2018@ukr.net
} 
connection with the pandemic in March 2020, Indonesian markets faced significant demand for local medicinal herbs, which led to increase in prices for finished products based on them by $20-30 \%$. A similar to Indonesian rise in the phytotherapy market has been observed since the beginning of 2020 in China, against the background of COVID-19, there is also a surge in demand for herbal products in Europe and the United States.However, in today's conditions, the relevance of medicinal plants is determined by a number of factors. Thus, manufacturers are now attracted by medicinal plants for their multi-vector and multifunctionality, the fact that it is a multi-purpose raw material, high margins, as well as increasing demand in recent decades - primarily due to growing demand for natural medicines and various plant-based products. Therefore, it is increasingly common to find information thatmedicinal plants growing is more profitable than growing wheat, rye or rapeseed, especially on a small area. According to Data Bridge Market Research, in the period from 2021 to 2028 , the market for medicinal plants will grow at an average annual rate of 5.34\% and is expected to reach 426 billion US dollars by $2028[4,14]$.

Secondly, in the context of the climate crisis, farmers have faced significant challenges, as it is increasingly difficult to grow traditional crops in many parts of the world due to the growing lack of moisture and drought. In this regard, medicinal crops are of particular importance - many of which are stress-resistant, adapted to arid conditions and highly profitable. For example, in the south of Ukraine today, due to global warming, it is possible to grow crops such as lavender, sage and plantain - previously the temperature of the south of this zone has not allowed them to grow. These crops are also economically attractive. Thus, according to experts, from each hectare of lavender crops you can get $60-70 \mathrm{~kg}$ of essential oil, the cost of which at the world market fluctuates at 100-270 dollars and today Ukraine can potentially compete with Bulgaria, which is the largest producer of lavender oil in Europe [6]. In addition, a by-product of oil production, lavender water (hydrolate), is in demand. In general, growing lavender can be accompanied by a profitability of more than $35 \%$. Among today's promising medicinal plants, scientists and practitioners also include plantain, which is widely cultivated in India - almost $60 \%$ of the market in this area is occupied by this country. This crop is resistant to low temperatures and drought and in general is one of the most unpretentious, and its cultivation may be accompanied by a high level of profitability. The economic attractiveness of plantain isfirstly due to the fact that it can bring a profit 12 times greater than wheat; secondly, by the fact that it is used for food, feed and medicinal purposes, which expands the possible sales channels. Strong argumentin favor of growing plantain is that it is one of the most unpretentious plants, and its plantations can be used from 3 to 5 years $[5,10]$.

The list of medicinal plants that are attractive from an economic point of view and have a number of other advantages in today's conditions is quite wide, which largely shapes the potential of medicinal plants in Ukraine and around the world. Of course, medicinal plants will not replace wheat, sunflower and corn in the fields, but they have won a certain niche in the agricultural market and their position is expected to grow, so the development of medicinal plants requires constant in-depth research.

\section{Review of literature}

It should be noted that, given the significant socio-economic importance of medicinal plants, the problems and prospects of their production have been studied by many scientists from different regions of the world. Thus, Egyptian scientists Nahla S. Abdel-Azim, Khaled A. Shams, Abdel Aaty A. Shahat, Moustafa M. El Missiry, Shams I. Ismail and Faiza M. Hammouda (2011) emphasize that the demand for medicinal plantsis growing in both developing and developed countries and they play an important role in health care, biodiversity conservation, economic development and trade. In addition, scientists from 
Egypt cite a set of factors that constrain the development of medicinal plants in this country and much of which, in our opinion, are typical for developing countries, in particular for Ukraine. Such deterrents are the lack of information among local residents about the requirements of the international market of medicinal plants, the lack of access to small producers of modern cultivation technologies, the lag in the development and implementation of growing medicinal plants methods on the basis of sustainable development, developing countries enter the international market through intermediaries, which does not bring significant benefits to local producers [2].

Scientists from Bangladesh Md. Abu Saiyem, Shaikh AbdusSabur, Mohammad Ismail Hossain, and Md. Akhtaruzzaman Khan and Mst. Fatema Begum (2020) investigate the economic feasibility of the production of medicinal plants on the example of Aloe vera by analyzing the costs, profits and profitability of growing this crop. Proving that the production of aloe vera is highly profitable business, the authors at the same time note that there is a need to create plantsprocessing and the introduction of initiatives by the government to develop medicinal plants [13]. For Ukraine, these issues are also extremely important in today's conditions, as only a small part of Ukrainian medicinal plants are processed within the state and the industry develops solely at the initiative of private producers in the complete absence of state support.

Taking to the attention Covid 19 pandemic in the world, the publication of Indonesian scientists Lutfi Chabib, Wildan Khairi Muhtadi, Muhammad Ikhwan Rizki, and Rifazul Aulia Rahman, Mohamad Rahman Suhendri, and Arif Hidayat (2018) is relevant in the context of plant production nanomedicine and the creation of immunomodulators. This approach once again confirms the versatility of medicinal plants and the multi-vector nature of their use [11]. The information from Africa, which has emerged since the beginning of the pandemic on the wormwood-based drug Covid Organics, which can be used against SARS-CoV-2 and SARS, is also very relevant today. However, studies of the effectiveness of the drug are still ongoing [17].

In turn, a generalizing description of medicinal plants is given by Indian scientists Ruchi R Gangwar, Shweta Chaudhary, Chandra Dev, Kiran Raana and Supriya (2019), who cite the main advantages of medicinal plants over traditional crops: they provide better returns; have very high domestic and export demand;can be stored for a long time and sold at a time when the best prices prevail at the market; generally well tolerated by drought; rarely attacked by pests and diseases; their production mostly requires minimal resources, therefore, the cost of cultivation is often lower compared to traditional crops;can be grown both in crop rotations together with traditional crops and on degraded lands. We believe that this information should be used primarily to promote medicinal crops among rural residents, among farmers and homeowners [3].

Sri Astutik, Jürgen Pretzsch and Jude Ndzifon Kimengsi (2019) analyze the production of medicinal plants in Asia by a very powerful and capacious study. This research focuses on the fact that at present time: medicinal plants play a significant role in the fight against poverty and the development of health care;there are sub regional differences - in South Asia, medicinal crops are aimed at supporting agriculture and traditional medicine, and in Southeast Asia and China, the focus is on the commercialization of the industry. However, scientists note that there are very limited studies on the commercialization of medicinal plants, especially those aspects that relate to the role of intermediaries, cycles of ups and downs, product quality [1].

Commenting on the above facts, we note that most studies on the development of medicinal plants are performed on the example of Asian countries, as there is concentrated world production of medicinal plants, as well as because Asian countries have long been awaresignificant socio-economic importance of medicinal plant growingin society and in government, and its development is a priority for many Asian countries and therefore is 
constantly on the field of view of scientists.Given this, Ukraine is a country with a large territory, favorable natural and climatic conditions for growing medicinal plants, favorable geographical location; it is possible to borrow the experience of leading countries in the production of these crops, which will positively affect rural employment, improve biodiversity, and diversify agriculturalproduction, improving the condition of soils and the economy as a whole. At the same time, most of the research on the development of medicinal plants is agronomic or studies the production of medicinal crops in the context of the development of the pharmaceutical industry. In Ukraine, in particular, the issues of commercialization of medicinal plants are practically unexplored, which led to the topic of this publication.

\section{Materials and Methods}

Calculations within this publication have been based on primary information of the Research Plant of Medicinal Plants of the Institute of Agroecology and Nature Management of the National Academy of Agrarian Sciences of Ukraine and secondary information of the State Statistics Service of Ukraine for 2018-2019 in terms of the most common crops in Ukraine. At the same time we operated with information characterizing the newly created plantations of medicinal plants in the specified period. With the help of statistical and economic method the analysis of dynamics of a number of indicators is carried out and the abstract-logical method of scientific research for theoretical generalizations and formulation of conclusions is applied.

\section{Results and Discussion}

The lack of information on the commercialization of medicinal plants and the production potential of the industry in Ukraine hinders its development, as potential producers among entrepreneurs and the rural population often do not risk starting a new business due to lack of knowledge.

Therefore, in order to gather information about the potential of medicinal plants, its advantages and disadvantages and to develop economically sound recommendations for the production of medicinal plants, the level of profitability, profitability, profitability and cost of production of individual crops was analyzed. The choice of such crops as chamomile, calendula, milk thistle, thyme, oregano, sage, nettle and lemon balm is due primarily to the fact that:

- the technology of production of these medicinal plants is relatively simple;

- it is possible to collect several crops per season and store dried medicinal plant raw materials for 1.5-3 years;

- there may be scaling of production;

- most of these plants are drought-resistant, can grow in harsh conditions and, accordingly, their production is adapted to the climatic conditions of southern Ukraine, where the issue of reformatting agricultural production due to the catastrophic state of soils and frequent droughts is acute;

- they are able to retain the content of nutrients in the soil, improve its structure, are good precursors for wheat, do not deplete the soil like sunflower, which currently predominates in the structure of crops;

- they are cost-effective crops, export-oriented, such that can be used in several areas;

- their production is most common in Ukraine [8].

In addition, there are a number of strong arguments in addition to those mentioned in favor of, for example, sage. This is the ability to assemble it with different types of 
equipment or manually, the constant demand for it, the attractive purchase price, as well as its fungicidal properties. In particular, this crop is a good precursor - yes, cereals sown after sage for three years are virtually unaffected by root diseases. Sage can also be used as an element of protection of gardens from pests. Plantations of sage in between rows can reduce the number of treatments in the garden from 17-20 to 2, provided there are 3-4 sage plants per fruit tree.

Such medicinal plant as chamomile, which is the most popular in the world and Ukrainian market of pharmaceuticals and veterinary medicine, is widespread and economically profitable. Ukraine imports medicinal chamomile, although favorable natural and climatic conditions and potential opportunities due to the technological simplicity of its production are incentive for the development of this crop in the country. Given that 3-4 chamomile crops can be harvested from the field during the season, the economic benefits of its production are obvious - the farmer's net profit can be up to UAH 300,000/ha at a starting price of UAH 25/kg [9].

Arguments in favor of lemon balm are that this perennial plant can grow on sandy soils, is actively cultivated on an industrial scale and is essential oil, which means the possibility of producing essential oils. They are a key component of lemon balm, for which it is often grown.Up to $35 \mathrm{~kg}$ of essential oil can be obtained from 1 hectare of lemon balm at a yield of 220-250 c/ha of raw mass or 35-40 c/ha of dry grass. In subsequent years, the yield of lemon balm increases by about a third. In addition, given that the most attractive among medicinal plants today are those that have multi-vector use - they can be used not only in pharmacology but also in food, perfume and other industries, the role of lemon balm is growing, asit is an essential oil, food-tasting and honey perennial plant. Not demanding to soils and climatic conditions, and therefore one that can adapt to the stressful conditions of the steppe of Ukraine, is the milk thistle plant. The advantage of the production of this plant, first of all, is the ability to improve the soil, which is extremely important for depleted soils of Ukraine.

According to the ratio of «minimum costs, minimum labor, minimum risks - maximum profit», a very promising crop for the South of Ukraine are a thymus or thyme. Thymus for growers is interesting because, first, this plant is perennial. Its plantings can be used for 5-6 years, in addition to harvesting twice a season. Secondly, thymus is very unpretentious and tenacious. Third, this plant looks good and smells great. And, fourthly, it has a wide range of applications - it is used in folk and official medicine, cosmetology and perfumery, food industry and cooking, so there are almost no problems with its implementation. In many countries, thymusis grown as a spicy plant. Thymus is in demand on the international market, and, accordingly, there are sales. In addition, having its own processing, from 1 hectare of thymus you can get at least $\$ 3$ thousand and additional funds will bring the sale of thymus honey [7].

General advantages of all medicinal plants include the fact that: medicinal herbs can be grown in any region and on different soils - you just need to choose the right species;raw materials are harvested only in the summer-autumn period, and its sale can last all year round. The fact that we are considering the feasibility of producing a group of medicinal plants is due to the fact that manufacturers advise never to rely on one crop - in the event of a collapse in prices for it, there may be losses. The best option is to combine the cultivation of a certain set of medicinal plants with the collection of wild ones. There is also a widespread recommendation to combine the cultivation and collection of inexpensive unpretentious plants and high-value crops to increase the profitability of medicinal crops.

According to the study, a characteristic feature of the cultivation of medicinal plants is that due to the relatively high costs faced by growers in the first year of production of perennial crops, expect a high level of profitability starting at least from the second year. In this regard, the analysis of the level of profitability and cost of production was performed 
through the prism of comparing the results of the 1st and 2nd year from the beginning of production of the group of basic medicinal plants. Yes, the information in Fig.1 shows that:

- for the second year since the beginning of cultivation, the production of thyme, oregano, sage and lemon balm goes from unprofitable to profitable - accompanied by a significant increase in profitability - up to $300 \%$ in terms of oregano in 2019 ;

- in terms of production of chamomile, calendula and milk thistle remains the same level of profitability as the first year;

- profitability of dog nettle increases from 40 to $125 \%$.

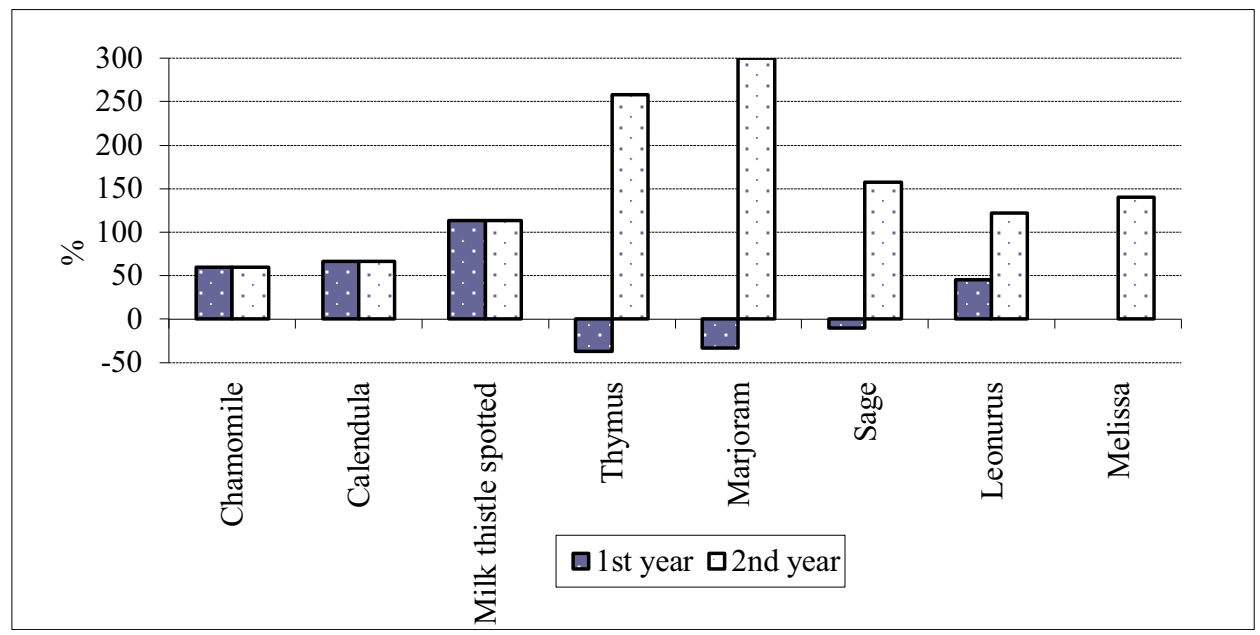

Fig. 1. Profitability of production of individual medicinal plants in the first and second year from the beginning of production, \%. Source:Developed by the authors using the data from the State Statistics Service of Ukraine.

Accordingly, the same positive trends can be traced in terms of profitability and profitability of production per 1 ha for the second year from the beginning of cultivation (Figs. 2, 3). High profitability of medicinal plant growing to some extent determines the types of diversity of medicinal plant products and its versatility. This figure also depends on the type of crop grown.

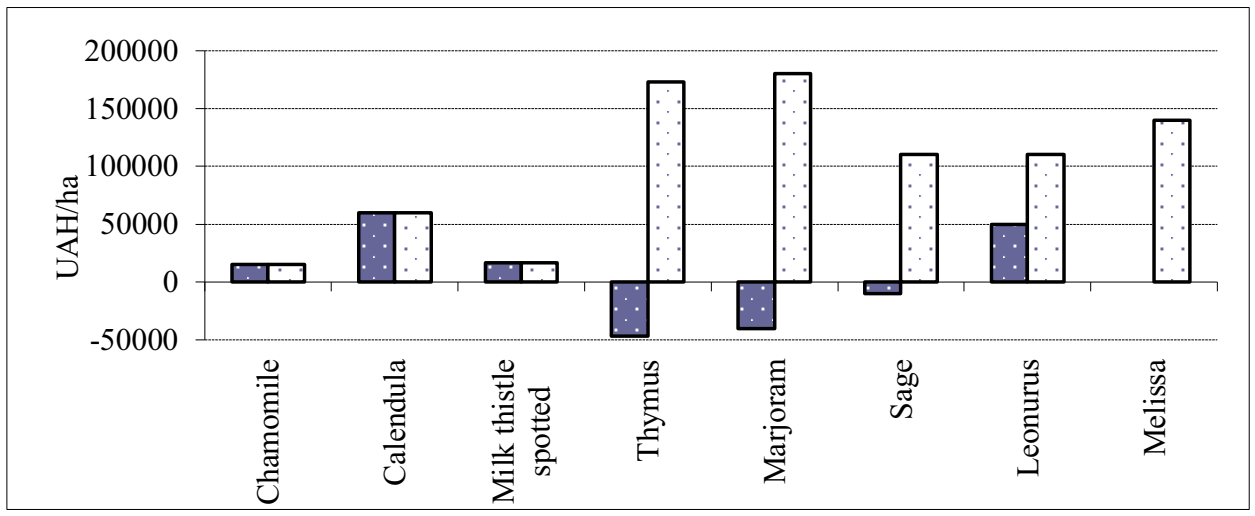

Fig. 2. Profit per 1 ha of crops of main medicinal crops in the first and second year from the beginning of cultivation, UAH. Source: Developed by the authors using the data from the State Statistics Service of Ukraine.

It is worth noting that the high profitability of the production of medicinal plants is inextricably linked with high labor intensity - so one hectare of medicinal plants can be 
spent labor and investment as per 100 hectares of grain. But with skillful business and a high yield of a hectare of medicinal herbs can earn up to 20 thousand dollars. If we compare with the production of grain in Ukraine, it is quite possible to earn 10-30 times more on medicinal plants than on wheat.

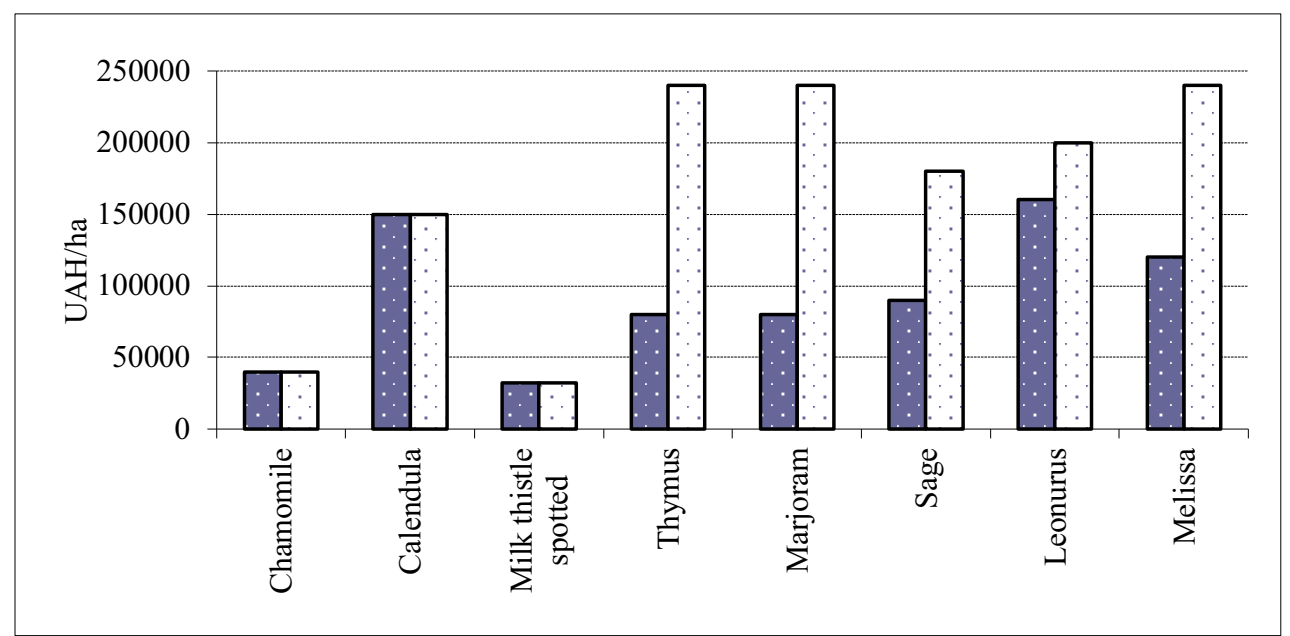

Fig. 3. Income per 1 ha of crops of main medicinal crops in the first and second year from the beginning of cultivation, UAH. Source: Developed by the authors using the data from the State Statistics Service of Ukraine.

In addition, the increase in the efficiency of production of medicinal plants, as found in the study for the second year from the beginning of cultivation is significantly influenced by lower costs compared to the first year (Fig. 4).

This is due to the fact that in the first years the entrepreneur buys everything necessary to ensure the production process - machinery, various equipment, splicing systems, planting material and more. In general, the initial investment in the cultivation of medicinal plants is much greater than in the production of cereals. Thus, in the first year of planting a plantation, an entrepreneur may need up to UAH 200,000 per hectare, but at the same time, as practical experience shows, the profit from one hectare of medicinal plants can be the same as from 10-50 hectares of grain [12].

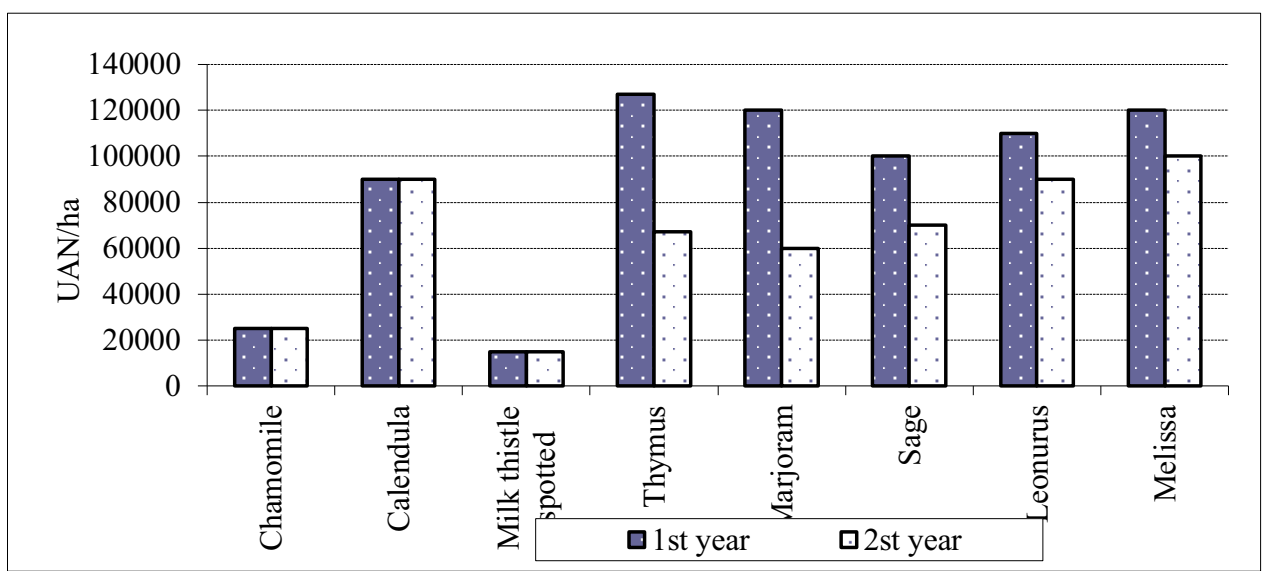

Fig. 4. The level of production costs per 1 ha of crops of major medicinal crops in the first and second year from the beginning of cultivation, UAH. Source: Developed by the authors using the data from the State Statistics Service of Ukraine. 
Mostly from the second to the fifth year (depending on the crops grown), the costs are directed directly to the growing process itself and the profitability becomes significantly higher than in previous years. This fact, along with a number of others, significantly affects the fact that the business of growing medicinal herbs has not become widespread in Ukraine at this stage of development. As a rule, most Ukrainian farmers seek to make a profit from the first year of production. Although, as already mentioned, if manufacturers were more informed, they probably would not have overlooked the production of medicinal plants, which in Ukraine is characterized by a low level of competition. After all, the advantages of this business are high profitability, the ability to start it and earn income even without start-up capital and even in small backyards, low market saturation. The main disadvantage of medicinal plants is the seasonality, which has already been mentioned. Despite the fact that medicinal herbs can be sold all year round, in the winter months, entrepreneurs, especially small ones, can suffer losses if stocks are depleted. The organization of raw material processing allows reducing the influence of the seasonal factor.

World experience shows that medicinal plants and products of their processing are products with high added value, in connection with which we also paid attention to value chains in terms of individual crops (Table 1). It was found that with the processing of medicinal raw materials and packaging of finished products, profitability increases even more.In 2019, in Ukraine, an average of 100-300 thousand UAH of gross income per hectare of medicinal herbs could be obtained per year. With all the necessary equipment and other necessary initial investment, and, for example, investing 100-150 thousand UAH in the cultivation of valerian, it was possible to collect it in the amount of about 300 thousand UAH. Information in the $1^{\text {st }}$ table shows that the production of medicinal plants only with primary processing is quite a profitable business. Each position in the set of medicinal plants is very individual and one that is constantly changing demand and profitability. It happens that there is a demand for some plants for several years in a row, and when they all run out, the demand grows rapidly.

Table 1. Value added chains in terms of individual medicinal plants, 2019. Source: compiled by the author according to Research station of the Institute of Agroecology and Environmental Management of NAAS of Ukraine.

\begin{tabular}{|l|l|}
\hline \multicolumn{1}{|c|}{ Elderberries of blackberry } & \multicolumn{1}{c|}{ Horse chestnut fruit } \\
\hline Raw price $=5 \mathrm{UAH} / \mathrm{kg}$ & Raw price $=5 \mathrm{UAH} / \mathrm{kg}$ \\
\hline Dry yield $(17 \%)=30 \mathrm{UAH} / \mathrm{kg}$ & Grinding $=1 \mathrm{UAH} / \mathrm{kg}$ \\
\hline Cleaning from a stalk $=35 \mathrm{UAH} / \mathrm{kg}$ & Dry yield $(55 \%)=11 \mathrm{UAH} / \mathrm{kg}$ \\
\hline $\begin{array}{l}\text { Drying }(5 \mathrm{UAH} / \mathrm{kg} \text { of moisture })+25 \mathrm{UAH}= \\
=60 \mathrm{UAH} / \mathrm{kg}\end{array}$ & $\begin{array}{l}\text { Drying }(5 \mathrm{UAH} \text { of moisture })+2,25 \mathrm{UAH}= \\
=13,25 \mathrm{UAH} / \mathrm{kg}\end{array}$ \\
\hline $\begin{array}{l}\text { Wage, } \mathrm{packaging}, \text { logistics }+5 \mathrm{UAH} / \mathrm{kg}= \\
=65 \mathrm{UAH} / \mathrm{kg}-\text { cost of dry weight }\end{array}$ & $\begin{array}{l}\text { Wage, } \text { packaging, logistics }+1 \mathrm{UAH} / \mathrm{kg}= \\
=14,25 \mathrm{UAH} / \mathrm{kg}-\text { cost of dry weight }\end{array}$ \\
\hline Selling price $90 \mathrm{UAH} / \mathrm{kg}$ & Selling price $22 \mathrm{UAH} / \mathrm{kg}$ \\
\hline Profitability $40 \%$ & Profitability $54 \%$ \\
\hline
\end{tabular}

The most profitable area in the field of medicinal plant growing is the processing of medicinal herbs, in particular the production of dry extracts (isolated from plants and dried active substances). For example, the eleuthero coccus processing line (the plant from which drugs for the treatment of nervous disorders are produced) in 2015 cost about 850 thousand dollars USA. The payback period of such a line is about one year. This is due to the fact that $1 \mathrm{~kg}$ of dry matter in the same period cost about $\$ 1,300$.US dollars and the cost of its production were only 160 dollars USA. That is, it is deep processing that provides high added value in the research area.

Thus, given the specifics of growing medicinal plants, achieving high profitability in the production and processing of medicinal plants, as a rule, stretched over time. Experts also 
note that the profitability of medicinal plant production depends on a number of factors, the main of which are: drying method, type of dryers, logistics, labor costs, selling price, product quality, and direction of sale - within the state or for export. Researchers and practitioners note that the main investments in the business of growing medicinal plants are related to wages. For example, the collection of valerian is still carried out manually;it is still not mechanized, even by the Germans and Americans. Therefore, the production of medicinal plants is also characterized by a specific cost structure - so, the greatest costs are for planting material, irrigation systems and wages [16].

For completeness of the analysis, comparisons of prices for medicinal plants and other crops in Ukraine were performed (Table 2). Information in the $2^{\text {nd }}$ table is a strong confirmation of the thesis stated at the beginning of the publication that the cultivation of medicinal plants is much more profitable than the cultivation of wheat, rye or rape. Thus, in 2019 , the price of one ton of medicinal plants was 19032,41 UAH, which is almost 5 times higher than the price of a ton of cereals and legumes, 4,2 times higher than the price of a ton of vegetables and 3 times higher than the price of a ton of fruits and berries.

Table 2. Dynamics of average prices of sold products of agricultural and medicinal crops for the period 2016-2019 in Ukraine. Source: Compiled by the author according to the State Statistics

Service of Ukraine.

\begin{tabular}{|l|c|c|c|c|}
\hline \multirow{2}{*}{\multicolumn{1}{|c|}{ Crops }} & \multicolumn{4}{|c|}{ Price.UAH/t } \\
\cline { 2 - 5 } & \multicolumn{4}{|c|}{ Years } \\
\cline { 2 - 5 } & $\mathbf{2 0 1 6}$ & $\mathbf{2 0 1 7}$ & $\mathbf{2 0 1 8}$ & $\mathbf{2 0 1 9}$ \\
\hline Grain andlegumes & 3414.0 & 3771.6 & 4315.0 & 3867.5 \\
\hline Vegetables & 3924.2 & 4136.1 & 4448.0 & 4497.0 \\
\hline Fruits and berries & 5863.8 & 8766.6 & 5054.0 & 6494.4 \\
\hline Medicinal & 16026.6 & 16026.6 & 19032.4 & 19032.4 \\
\hline
\end{tabular}

The expert of the market of medicinal plants Gubanyov O. (2020) notes that depending on the market situation the prices for medicinal raw materials change from year to year, therefore it is difficult to make predictions for the future. For example, ginseng, depending on the year of sale, can cost from $\$ 50$ to $\$ 250$ per ton. Almost $70 \%$ of the market of medicinal plant raw materials in Ukraine is in «the shadows» [15].

A positive trend for manufacturers is that prices for medicinal plants have been steadily rising in recent years. Of course, manufacturers can profitably sell cultivated medicinal plants under the condition of well-established production, developed modern cultivation technologies, and well-established sales channels. The most common are two ways of selling: 1) sell the entire crop to a wholesale trader. They usually buy any medicinal plant in large quantities - from $500 \mathrm{~kg}$. Then the raw materials are finished to the required quality parameters, radiation control is carried out, homogeneous certified batches are created and they are sold to large producers in Ukraine and for export. The advantage of such sales is a minimum of time to generate income, the disadvantage is a relatively low selling price, because wholesale companies usually buy raw materials at minimum prices; 2) direct contact with a manufacturing plant engaged in the processing of medicinal plants medicinal plants are purchased by pharmaceutical companies, food manufacturers (teas, spices), representatives of the cosmetology and perfumery, manufacturers of extracts and essential oils, veterinary drugs and feeds, etc. In this case, it is possible to sell the product at a higher price, but it takes more time, as manufacturing companies are demanding on the quality of raw materials and may need its expertise to confirm the proper quality of goods.In addition, in order to establish a direct connection with companies engaged in the production of various products based on plant materials, medicinal plant manufacturers also need to make a lot of effort, spend a lot of time and money in advance. To do this, you need to systematically study the demand for medicinal plants in a particular region or regions 
and in the world as a whole, continuously search for channels and outlets, study the market and gather information about potential competitors. Experts note that ideally, you need to find and develop your markets before you start growing.

\section{Conclusion}

Despite the fact that the branch of medicinal plant growing in Ukraine is at the stage of formation, nevertheless, we believe that it can become the main source of income growth of the rural population and a significant source of filling the state budget. First of all, Ukraine has a rich natural potential and favorable agro-climatic conditions which allow growing a wide range of medicinal plants, almost throughout the territory;second, Ukraine's geographical location makes international markets accessible; thirdly, prices and demand for medicinal plants in the world are growing steadily, which makes their production increasingly economically attractive and in Ukraine it can be considered as a very attractive area for investment and as a very affordable type of business, especially for small businesses and rural population. This is evidenced by the relatively high profitability (40$300 \%$ and above, depending on the culture) and the profitability of the production of medicinal crops, demonstrated in this publication. At the same time, the rural population and entrepreneurs in rural areas in Ukraine are poorly informed about the economic attractiveness of the production of medicinal plants and there is no state support for this type of activity in the country. Therefore, taking into account, first of all, the significant production potential of medicinal plant growing and high profitability of this type of business in Ukraine, it is time to develop and implement an effective policy to encourage the cultivation of medicinal plants. It should be borne in mind that the business of growing medicinal plants, which are mostly perennials, requires the highest costs in the first year after the start of production.

Therefore, the main tools of this policy, as evidenced by international experience, should be actions to support potential producers: - the introduction of tax holidays for farmers who start a business in the field of medicinal crops; - programs of preferential crediting of producers of medicinal plants; - establishment of rent for land plots used for growing medicinal plants not more than $50 \%$ of their normative monetary value; - increase of the minimum lease term of land plots provided for growing medicinal plants up to 20 years; - providing subsidies for the cultivation of medicinal plants, the size of which will depend on their importance - those that are in great danger of extinction; those whose sources of supply are sharply reduced; those who need support; - providing subsidies for the purchase of special machinery and equipment and for the establishment and care of young perennial plantations of medicinal plants before they enter the fruiting phase.

\section{References}

1. S. Astutik, J. Pretzsch, J. Ndzifon Kimengsi, Asian Medicinal Plants' Production and Utilization Potentials: A Review file://C:/Documents\%20and\%20Settings/User/\%D0\%9C\%D0\%BE\%D0\%B8\%20\%D 0\%B4\%D0\%BE\%D0\%BA\%D1\%83\%D0\%BC\%D0\%B5\%D0\%BD\%D1\%82\%D1\%8 B/Downloads/sustainability-11-05483-v2\%20(2).pdf

2. N.S. Abdel-Azim, K.A. Shams, A.A.A. Shahat et al., Research Journal of Medicinal Plants 5, 136-144 (2011) DOI: 10.3923/rjmp.2011.136.144

3. R.R. Gangwar, Sh. Chaudhary, Ch. Dev et al., Journal of Pharmacognosy and Phytochemistry SP5, 396-398 https://www.phytojournal.com/archives/2019/vol8issue5S/PartI/SP-8-5-63-306.pdf 
4. Global Medicinal Herbs Market - Industry Trends and Forecast to 2028 (2021) https://www.databridgemarketresearch.com/reports/global-medicinal-herbs-market

5. Growing plantain is 12 times more profitable than wheat (2019) http://agrobusiness.com.ua/agrobusiness/item/12557-vyroshchuvannia-podorozhnyka-u-12-razivvyhidnishe-nizh-pshenytsi.html

6. It is profitable to grow lavender in Ukraine (2018) https://superagronom.com/news/3675-v-ukrayini-vigidno-viroschuvati-lavandu

7. O. Korol, Herbs as a business for a farmer - in the October issue of the magazine "Agroindustry» (2018) https://uhbdp.org/en/news/project-news/1721-travi-yak-biznesdlya-fermera-v-zhovtnevomu-vipusku-zhurnalu-agroindustriya

8. T. Mirzoieva, V. Heraimovych, Y. Loshakova et al., EMMFT-2020. Web Conf. 244, 03027 (2021) DOI: org/10.1051/e3sconf/202124403027

9. V. Pavlovich, TOP-5 most promising medicinal plants for farmers (2018) https://kurkul.com/spetsproekty/332-top-5-nayperspektivnishih-likarskih-roslin-dlyafermeriv

10. Plantain cultivation is potentially a highly profitable business (2019) https: // www.seeds.org.ua/kultivuvannya-podorozhniku-mozhe-stati-pributkovim-biznesom/

11. Lutfi Chabib, Wildan Khairi Muhtadi et al., MATEC Web Conf. 154 (2018) DOI: org/10.1051/matecconf/201815404006

12. N.V. Privedenyuk Balanced using of nature. (2016)4, 62-65.

13. Md. Abu Saiyem, Shaikh Abdus Sabur, Mohammad Ismail Hossain et al., Research in $\begin{array}{lllll}\text { agriculture, livestock and fisheries } & \mathbf{7 ( 1 )}, \quad 75-81 & \text { (2020) }\end{array}$ DOI: https://doi.org/10.3329/ralf.v7i1.46833

14. M. Shestakov, COVID-19 sharply increased the quantity of drugs and food supplements (2020) https://www.rvc.ru/press-service/media-review/nti/160353/

15. Trends in cultivation and sales (2020) https://uhbdp.org/ua/news/project-news/2461maizhe-70protsent-rynku-likarskoi-roslynnoi-syrovyny-v-ukraini-perebuvaie-v-tinitendentsii-vyroshchuvannia-ta-realizatsii

16. True-herb: how an stock market trader became an exporter of medicinal herbs and why he is so calm (2018) https://agroday.com.ua/2018/01/23/u-gorodi-buzyna-dveritravy-trymatysya-koreniv/

17. Wormwood tincture is a cure from coronavirus from Africa (2020) https://www.dw.com/ru/nastojka-polyni-lekarstvo-iz-afriki-protiv-koronavirusa/a53454415 